\title{
Microsporidiosis in the Caribbean spiny lobster Panulirus argus from southeast Florida, USA
}

\author{
Yasunari Kiryu ${ }^{1, *}$, Donald C. Behringer ${ }^{2}$, Jan H. Landsberg ${ }^{1}$, Barbara D. Petty ${ }^{2,3}$ \\ ${ }^{1}$ Florida Fish and Wildlife Conservation Commission, Fish and Wildlife Research Institute, 100 Eighth Avenue SE \\ St. Petersburg, Florida 33701, USA \\ ${ }^{2}$ Program in Fisheries and Aquatic Sciences, School of Forest Resources and Conservation, University of Florida, \\ 7922 NW 71 Street, Gainesville, Florida 32653, USA \\ ${ }^{3}$ Large Animal Clinical Sciences, College of Veterinary Medicine, 7922 NW 71 Street, University of Florida, Gainesville,
} Florida 32653, USA

\begin{abstract}
Two specimens of the Caribbean spiny lobster Panulirus argus captured by lobster fishers offshore of southeast Florida, USA, between late 2007 and early 2008 had completely white abdominal muscle tissue with a 'cooked' appearance. Wet-mount examination of the skeletal muscle tissue revealed masses of microsporidian spores. Histopathology of longitudinally sectioned skeletal muscle showed that the microsporidian spores displaced much of the muscle mass, but were interspersed with small empty vacuoles (approximately $5 \mu \mathrm{m}$ in diameter) found adjacent to necrotic skeletal muscle. Skeletal muscle showed both liquefactive and coagulative necrosis. Transmission electron microscopy of the microsporidian spores revealed characteristics - including microvilli extending from the surface of the exospore, a unikaryotic spore (width $1.0 \pm 0.13 \mu \mathrm{m}$, range 0.8 to 1.4 $\mu \mathrm{m}$; length $1.4 \pm 0.11 \mu \mathrm{m}$, range 1.2 to $1.6 \mu \mathrm{m}$; mean $\pm \mathrm{SD}, \mathrm{N}=16$ ), and an isofilar polar filamentconsistent with the genus Ameson, which is known to infect other palinurid lobsters. Microsporidiosis in Caribbean spiny lobsters has rarely been reported within the lobster's range, with only one brief report coming from the Florida Keys in 1976. Potential risks to the lobster fishery are unknown but warrant further study.
\end{abstract}

KEY WORDS: Microsporidia $\cdot$ Infection $\cdot$ Parasite $\cdot$ Spiny lobster $\cdot$ Panulirus argus $\cdot$ Skeletal muscle Necrosis · Transmission electron microscopy

Resale or republication not permitted without written consent of the publisher

\section{INTRODUCTION}

Spiny lobsters have few reported diseases (Evans et al. 2000); however, with continued interest in their culture and grow-out, increased health problems are anticipated. Microsporidian parasites have been reported to infect palinurid lobsters and are potentially pathogenic to wild stocks (Bach \& Beardsley 1976, Evans et al. 2000). The phylum Microsporidia is currently classified within the kingdom Fungi, but their taxonomic status is under debate (Hibbett et al. 2007). Microsporidiosis in decapod crustaceans is caused by several genera of parasitic microsporidia, including Abelspora, Agmasoma, Ameson, Endoreticulatus, Gurleya, Inodosporus, Nadelspora, Nosema, Ormieresia, Pleistophora and Thelohania (Sprague \& Couch 1971, Vivarès et al. 1977, Azevedo 1987, Olson et al. 1994, Lightner 1996, Azevedo et al. 2000, Wang \& Chen 2007). Microsporidia usually infect the skeletal musculature, causing mechanical damage and altering the biochemical composition of the host tissue (Findley et al. 1981). The combined effect changes the coloration of normal muscle tissue from translucent gray to cottony-white.

The possible effects of microsporidiosis on crustacean fisheries and aquaculture are considerable, including the reduced marketability of cultured penaeid shrimp (Lightner 1996). Crustaceans with microsporidiosis are not aesthetically pleasing, and the muscle is in poor condition for the market, thereby reducing its commercial value.

Although there is a known history of microsporidiosis in decapods in Florida, e.g. Agmasoma duorara in 
wild pink shrimp Farfantepenaeus duorarum (Iversen \& Manning 1959, Kruse 1959), microsporidiosis in the Caribbean spiny lobster Panulirus argus is poorly studied (Shields et al. 2006). To our knowledge, the only brief report (Bach \& Beardsley 1976) did not identify the specific parasite. The present report presents the results of pathological investigations of 2 Caribbean spiny lobster specimens - one collected by a recreational lobster fisher offshore of Pompano Beach, Florida (approximately $26^{\circ} 13^{\prime} \mathrm{N}, 80^{\circ} 01^{\prime} \mathrm{W}$ ), on December 17, 2007, and another collected by a recreational fisher offshore of Jupiter, Florida (approximately $26^{\circ} 55^{\prime} \mathrm{N}, 80^{\circ} 01^{\prime} \mathrm{W}$ ), on March 31,2008 . After removing the carapace, the fishers noticed an unusual white color to the abdominal skeletal muscle tissue. Although these 2 reports may have just been coincidental, considering that they came shortly after the discovery of $P$. argus Virus 1 (PaV1), the first naturally occurring viral pathogen found infecting any lobster (Shields \& Behringer 2004), further investigation was warranted. PaV1 has been well described in the Florida Keys (Behringer et al. 2006, 2008, Butler et al. 2008) and along the Caribbean coast of Mexico (Huchin-Mian et al. 2008). Given the importance of $P$. argus to recreational and commercial fisheries and the increased awareness of disease generated by reports of PaV1, we anticipate that fishers will more likely report incidences of microsporidiosis if it is indeed increasing in prevalence and emerging as a pathogen of concern.

\section{MATERIALS AND METHODS}

The abdomen of the Pompano Beach Panulirus argus specimen, including the shell and skeletal muscle, was frozen and later shipped to the University of Florida in Gainesville. The same tissue from the Jupiter specimen was shipped overnight on ice within $24 \mathrm{~h}$ of collection to the Florida Fish and Wildlife Conservation Commission's Fish and Wildlife Research Institute (FWRI), St. Petersburg, Florida. Upon arrival at each institution, the condition of the lesioned tissue was documented with digital macrophotographs and assessed using wetmount light microscopy. Skeletal muscle was also smeared onto a glass slide and stained with a Diff-Quick stain kit (IMEB). Small sections of skeletal muscle $(10 \times 5 \times 5 \mathrm{~mm})$ were fixed in $10 \%$ buffered formalin, embedded in either paraffin (at University of Florida) or JB-4 resin (at FWRI). Slides were stained with hematoxylin and eosin (H\&E), periodic acid Schiff/ metanil yellow (PAS-MY) and thionin (Quintero-Hunter et al. 1991), and examined histopathologically using light microscopy. Light photomicrographs were captured with a microscope (Olympus BX51) equipped with a digital camera (Olympus DP71). A smaller piece of the skeletal muscle (approximately $1 \times 1 \times 1 \mathrm{~mm}$ ) from each lobster was processed for transmission electron microscopic (TEM) examination. At FWRI, the tissue was fixed overnight in Trumps fixative ( $4 \%$ formaldehyde, $1 \%$ glutaraldehyde, $50 \mathrm{mM} \mathrm{NaH} \mathrm{PO}_{4}, \mathrm{pH}$ 7.2) followed by post-fixation in $1 \%$ osmium tetroxide $\left(\mathrm{OsO}_{4}\right)$ for $1 \mathrm{~h}$. Tissues were subsequently dehydrated in a graded ethanol series, infiltrated with epoxy propylene oxide and embedded in epoxy resin. The epoxy block was then sectioned with an EM UC6 ultramicrotome (Leica Microsystems), stained with uranyl acetate followed by lead citrate, and examined with a TEM (JEM-1400, JEOL) equipped with a digital camera (ORIUS $^{\mathrm{TM}}$ SC1000 CCD, GATAN). By capturing digitized TEM images with an embedded scale bar, the approximate spore size was determined by measuring maximum widths and heights $(\mu \mathrm{m})$ of randomly selected mature pyriform spores $(\mathrm{N}=16)$. The epoxy block was also thick-sectioned $(1 \mu \mathrm{m})$ and stained with toluidine blue for confirmation of spores by light microscopy. At the University of Florida, the tissue for TEM examination was processed by the Electron
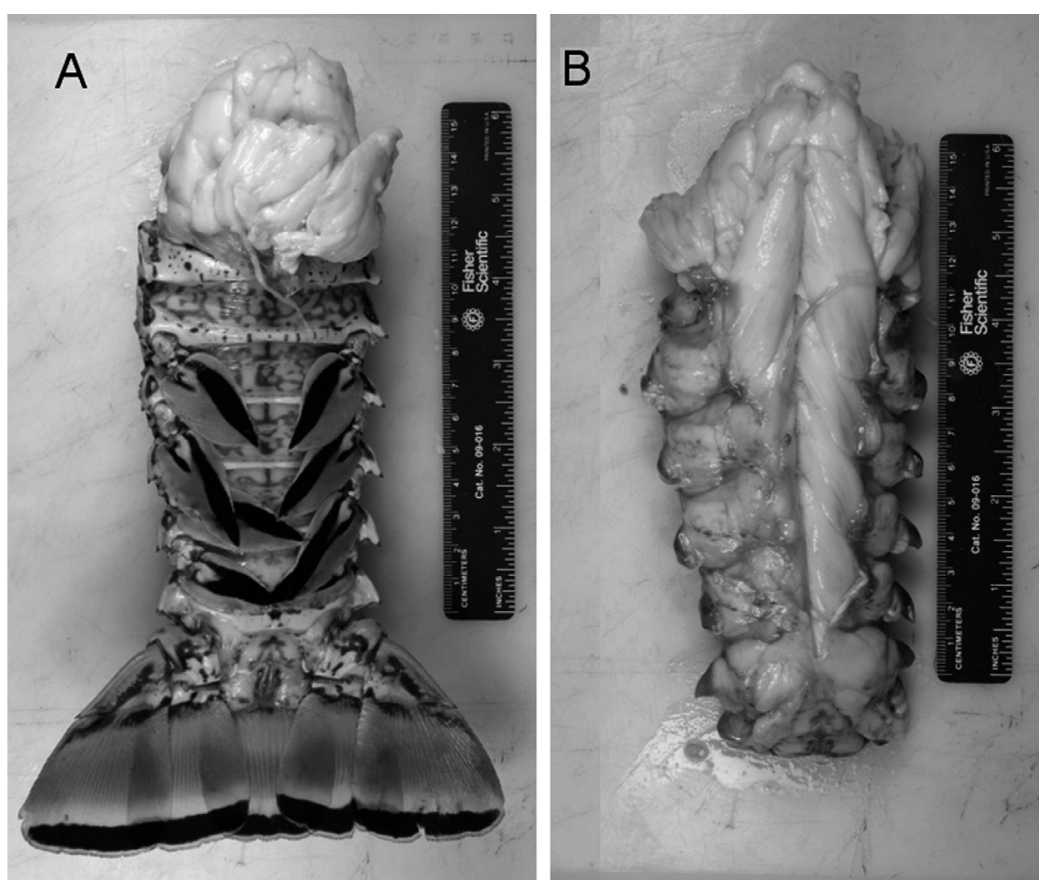

Fig. 1. Panulirus argus. Specimen from the Jupiter site. (A) Abdomen and telson with shell attached and the white-discolored skeletal muscle seen at the top. (B) White-discolored skeletal muscle of abdomen with shell and telson removed 
Microscopy BioImaging Laboratory using a laboratory microwave (PELCO ${ }^{\circledR}$ BioWave with ColdSpot, Ted Pella). Microwave settings were as follows: sample temperature restricted to $37^{\circ} \mathrm{C}$ using a ColdSpot temperature probe, vacuum set at 22 bars, and microwave power set at $180 \mathrm{~W}$. Tissue was fixed in Trump's fixative for $45 \mathrm{~s}$ under vacuum, washed 3 times with $0.1 \mathrm{M}$ sodium cacodylate buffer for $45 \mathrm{~s}$ each time; postfixed with $2 \%$ buffered $\mathrm{OsO}_{4}$ under vacuum (1 min at room temperature $[\mathrm{RT}], 45 \mathrm{~s}$ microwave [MW], $3 \mathrm{~min} \mathrm{RT}$ ), washed twice with water for $45 \mathrm{~s}$ each time, and dehydrated in a graded acetone series for $45 \mathrm{~s}$ each time and then twice in $100 \%$ acetone for $45 \mathrm{~s}$ each time. Dehydrated samples were then infiltrated in a graded acetone-Spurr's resin series (at $250 \mathrm{~W}$ ) for 3 min under vacuum and embedded in $100 \%$ Spurr's resin, then polymerized at $60^{\circ} \mathrm{C}$ for $2 \mathrm{~d}$. Cured sample resin blocks were trimmed with an EM TRIM specimen trimmer (Leica Microsystems). Sections were cut with an UltraCut R ultramicrotome (Leica Miscrosystems) and ultrathin sections were collected on 200 mesh copper grids. Ultrathin sections were post-stained with $2 \%$ aqueous uranyl acetate and Reynold's lead citrate and examined with a H-7000 transmission electron microscope (Hitachi High Tech- nologies America) operated at $75 \mathrm{kV}$. Digital images were acquired with a camera (MegaViewIII, Soft Imaging Solutions).

\section{RESULTS}

The length of each spiny lobster's abdomen from anterior of the first segment to the posterior end of the telson was $196 \mathrm{~mm}$ (Jupiter specimen) and $144 \mathrm{~mm}$ (Pompano specimen). On gross examination, the skeletal muscle was totally white and had a cotton-like

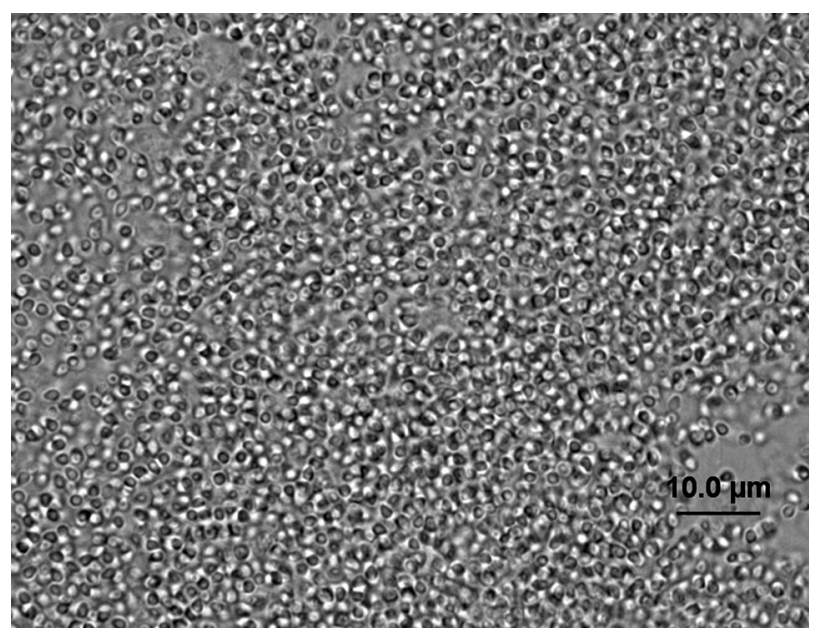

Fig. 2. Panulirus argus. Specimen from the Jupiter site; photomicrograph of the skeletal muscle tissue wet mount showing numerous microsporidia spores chalky appearance (Fig. 1). The texture of the muscle from the fresh Jupiter specimen was relatively firm. The muscle tissue from the frozen and thawed Pompano specimen appeared flaccid, but this texture was probably due to freezing.

Initial wet-mount light microscopy of the skeletal muscle tissue revealed masses of single-celled spores (Fig. 2). The sporophorous vesicles (SPV or sporont) typically associated with Thelohania or Agmasoma spores were not observed. Slides stained with DiffQuick revealed spores in which the nucleus was located eccentrically to centrally (Fig. 3).

Histopathologic examination revealed massive aggregates of tiny spores $(<2.0 \mu \mathrm{m})$ interspersed within the myosepta and located between muscle bundles (Fig. 4). Each spore had a basophilic-staining nucleus (in H\&E). In longitudinally sectioned skeletal muscle, vacuoles (ca. $5 \mu \mathrm{m}$ diameter) were commonly found adjacent to the necrotic skeletal muscle and among the masses of spores (Figs. 4 \& 5). The skeletal muscle showed both liquefactive and coagulative necrosis (Figs. $4 \& 5$ ). Coagulative necrosis tended to be accompanied by karyolysis of the myocyte nuclei (Fig. 4). In contrast, the myocytes in the remnants of muscle fibrils contained karyorrhexic and pyknotic nuclei and occasionally stained lightly PAS-positive (Fig. 5). These characteristics, in addition to the presence of pooled proteinaceous fluid, were indicative of liquefactive necrosis (Fig. 4). However, because the tissue samples were not fixed immediately following the lobsters' deaths, postmortem tissue degradation must be considered in addition to actual pathologic changes. Spore aggregates located among the necrotic muscle affected by liquefactive necrosis stained lightly basophilic (Fig. 4). Presumably these spore cells underwent degeneration or necrosis.

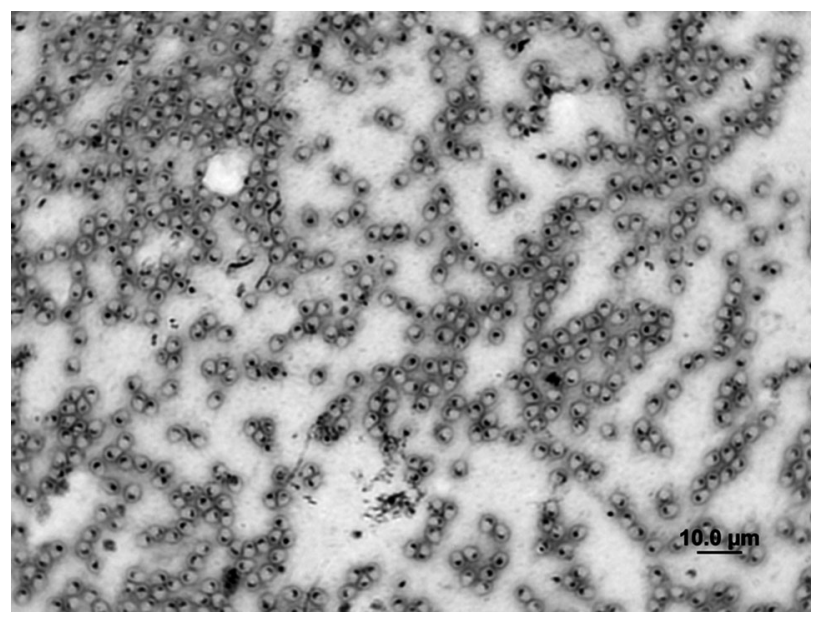

Fig. 3. Panulirus argus. Specimen from the Jupiter site; photomicrograph of the skeletal muscle smear stained with Diff-Quick. Nucleus of the spores located eccentric to central 
Ultrastructurally, spores and sporoblasts were found freely within the sarcoplasm of the muscle cells. Mature spores were ovoid to pyriform, with a broadened base (Fig. 6A; mean width \pm SD $1.0 \pm 0.13 \mu \mathrm{m}$, range 0.8 to $1.4 \mu \mathrm{m}$; mean length $\pm \mathrm{SD} 1.4 \pm 0.11 \mu \mathrm{m}$, range 1.2 to $1.6 \mu \mathrm{m} ; \mathrm{N}=16$ ). The spore structure con-

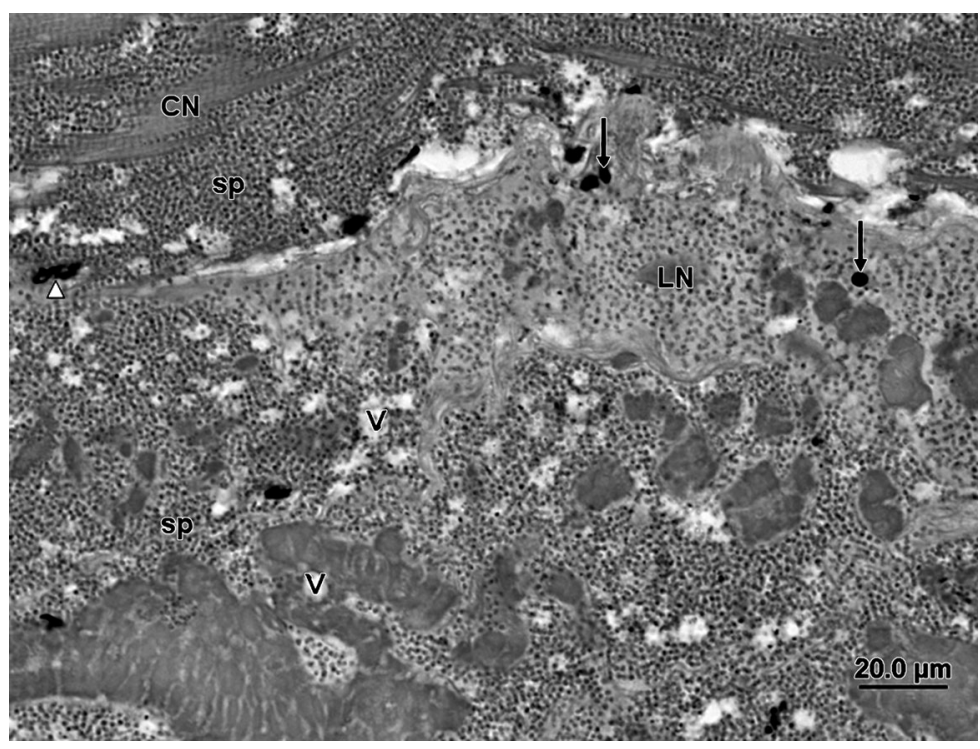

Fig. 4. Panulirus argus. Specimen from the Jupiter site. Histological section of the skeletal muscle showing numerous microsporidia spores (sp) surrounding coagulative $(\mathrm{CN})$ and liquefactive necrosis $(\mathrm{LN})$ of the skeletal muscle (H\&E, JB-4 section). Vacuoles (V) were commonly found adjacent to the necrotic skeletal muscle tissues among the mass of spores. Karyorrhexic (white arrowhead) and pyknotic nuclei (arrows) of the myocytes were hallmarks of necrosis of the skeletal muscle

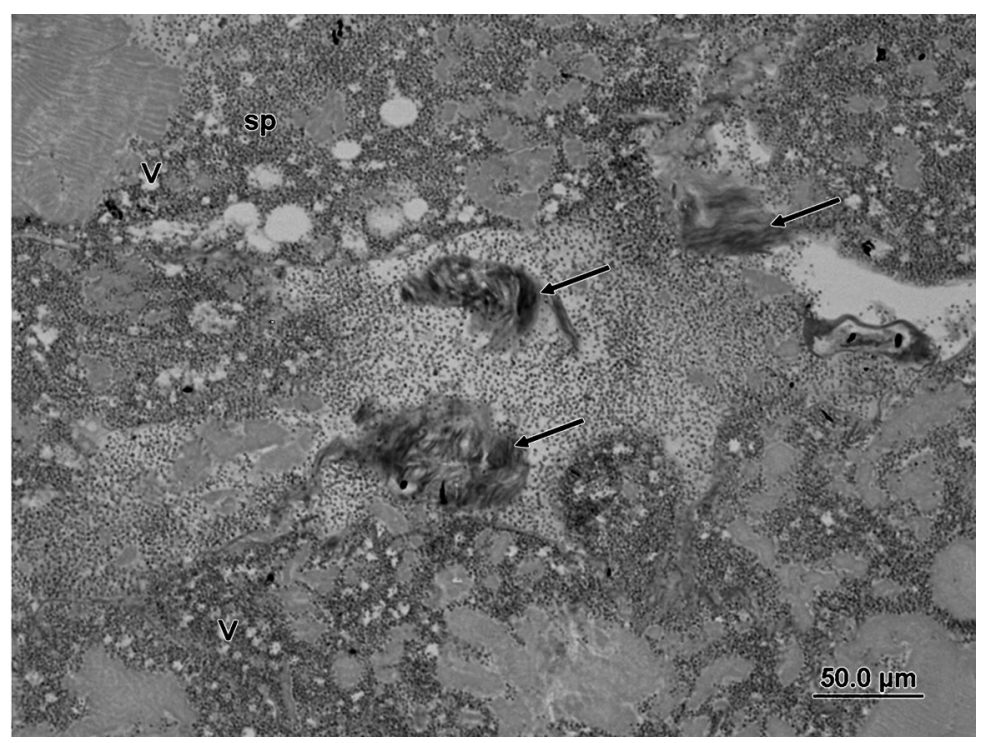

Fig. 5. Panulirus argus. Specimen from the Jupiter site. Histological section of the skeletal muscle with numerous microsporidia spores (sp) (PAS-MY, JB-4 section). Note PAS-positive necrotic muscle tissues (arrows). V: vacuoles sisted of external microvilli (Fig. 6) surrounding the exospore (approximately $0.02 \mu \mathrm{m}$ in thickness), which, in turn, covered the endospore (ca. $0.02 \mu \mathrm{m}$ in thickness). Within the sporoplasm, a single nucleus was found at the posterior pole, and the polaroplast and anchoring disc were located at the anterior pole (Fig. 6A). The isofilar polar filament had 7 to 8 turns (Fig. 6). TEM sections consisted mostly of mature spores, but some regions of the muscle contained high concentrations of sporoblasts undergoing cytokinesis (Fig. 7).

\section{DISCUSSION}

The lobsters examined in this study appeared to be in an advanced stage of microsporidiosis based upon the grossly visible extensive infestation of the abdominal muscle, the highly abundant spores detected through histopathology and the dominant presence of mature spores.

Invertebrates often undergo postmortem autolysis or liquefactive necrosis, whereas coagulative necrosis is often referred to as a 'cooked' appearance that retains the cellular architecture, as defined in general pathology nomenclature (Jones \& Hunt 1983, Roberts 1989, Couch \& Fournie 1993). Liquefactive necrosis of the skeletal muscle due to extensive microsporidian infection has been reported in other crustaceans, such as the freshwater crayfish Cherax tenuimanus (Langdon 1991) and blue crab Callinectes sapidus (Findley et al. 1981). Coagulative skeletal muscle necrosis has also been found during the acute phase of infectious myonecrosis virus (IMNV) syndrome in cultured Pacific white shrimp Litopenaeus vannamei (Lightner et al. 2004, Poulos \& Lightner 2006). Shrimp in an advanced chronic phase of myonecrosis progress from coagulative to liquefactive necrosis (Lightner et al. 2004). In spite of the massive number of spores invading the skeletal muscle tissues in our specimens, coagulative necrosis was observed (recognized as gross changes in the muscle color from translucent gray to white). We speculate that microsporidian spores may produce compounds that suppress lysis and effectively 'fix' the tissue, resulting in a characteristic 'cooked' appearance. Stephens et al. (2003) described microsporidiosis lesions in the western rock lobster Panulirus cygnus in Australia as resembling cooked muscle. 


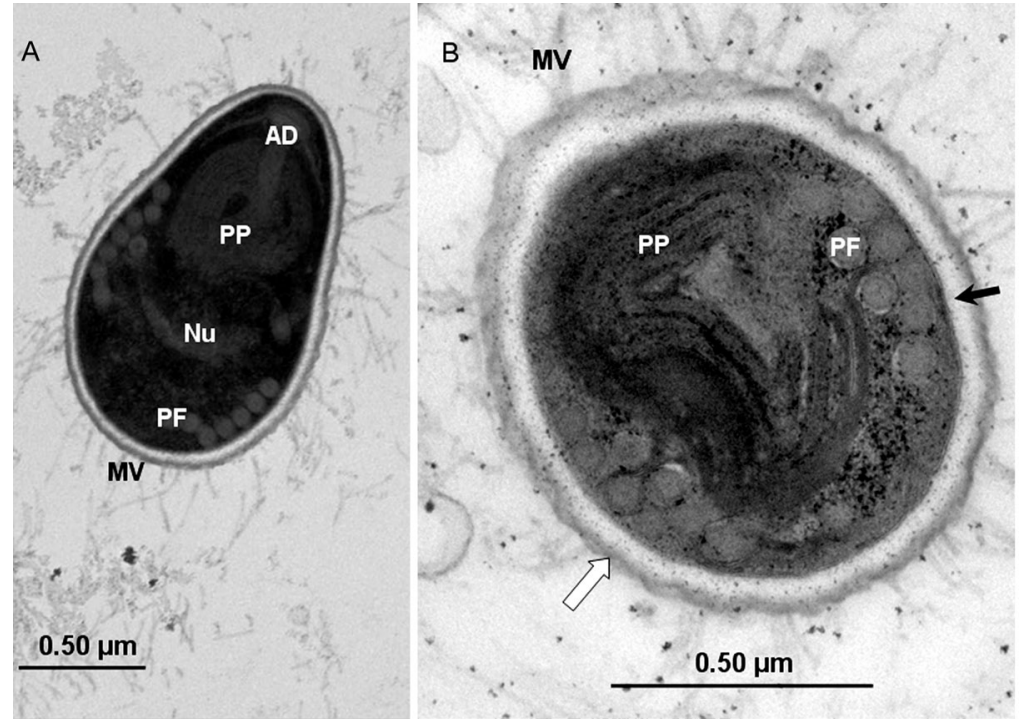

Fig. 6. Transmission electron micrographs of mature single microsporidian spore. (A) Specimen from Jupiter site: longitudinally sectioned spore showing microvilli (MV), nucleus (Nu), polar filament (PF), polaroplast (PP) and anchoring disc (AD). (B) Specimen from Pompano Beach site: cross-sectioned spore showing the MV, exospore (white arrow), endospore (black arrow), $\mathrm{PF}$ and PP

In Australia, the ornate lobster Panulirus ornatus and western rock lobster infected with microsporidia had spores measuring 1.4 to $1.8 \mu \mathrm{m}$ by 2.0 to $2.4 \mu \mathrm{m}$ (measured by TEM) and in the range of 1.0 to 2.0 $\mu \mathrm{m}$ (measured by light microscopy), respectively

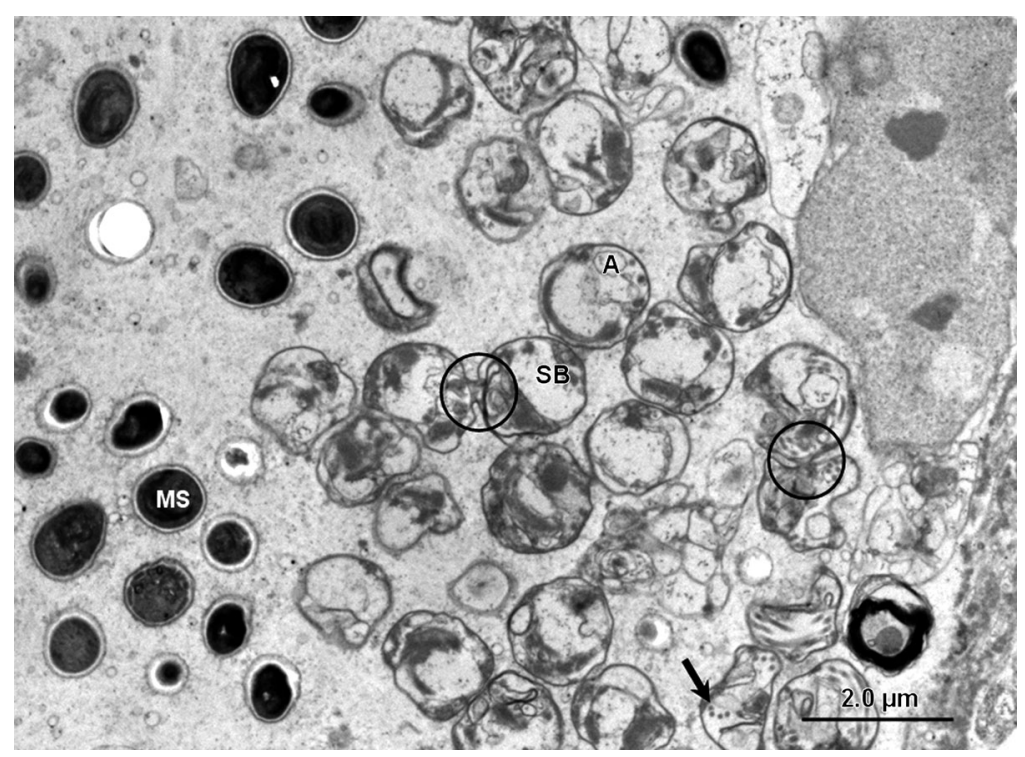

Fig. 7. Transmission electron micrograph of a concentration of mature spores and dividing sporoblasts in specimen from the Pompano Beach site. Sporoblast (SB), mature spore (MS), anchoring disc (A), developing polar filament (black arrow) and sites of sporoblast cytokinesis (within black circles)
(Dennis \& Munday 1994). Dennis \& Munday (1994) proposed that the microsporidian parasites from these palinurid lobsters be identified as Ameson sp. (Sprague \& Couch 1971) based on key morphological characteristics. Other cases of microsporidiosis in decapod crustaceans that have been attributed to Ameson include those affecting the penaeid shrimp Parapenaeus longirostris (Campillo \& Comps 1977) and the portunid crabs Carcinus maenas, C. mediterraneus (Vivarès \& Sprague 1979), Cancer pagurus (Vivarès \& Azevedo 1988), Callinectes sapidus (Findley et al. 1981) and Portunus pelagicus (Shields \& Wood 1991). A spore size of $1.2 \times 2.0 \mu \mathrm{m}$ was documented for $A$. nelsoni from penaeid shrimp (Lightner 1996). Based on morphological characteristics described for Ameson, including microvilli extending from the surface of the exospore, a unikaryotic spore and an isofilar polar filament (Shields \& Wood 1991, Dennis \& Munday 1994, Lightner 1996), the microsporidian identified from our lobster specimens is most probably a member of this genus.

The microsporidian species causing the infection described here in Panulirus argus remains to be conclusively identified. Along with the morphological features, molecular-based techniques must be used to identify this parasite in future work. Potential risks to the lobster fishery are also currently unknown, but are being investigated. The Caribbean spiny lobster fishery is one of the most valuable fisheries in the Florida and throughout the Caribbean (Hunt 2000, FAO 2001, 2004), so determining the potential for significant effects on this lucrative industry is of the utmost importance.

Acknowledgements. This research was supported by Florida State funds under the Fish and Wildlife Health program. Special thanks to D. Dickinson and D. Austin, who sent the specimens for examination to FWRI and University of Florida, respectively. M. Bakenhaster, C. Brown and A. Long at FWRI assisted with specimen examination and preparation. We thank N. Perry, M. Tabuchi and S. Leslie for their technical assistance in processing histology slides, and Y. Walters, B. Kang and K. Kelley, who processed tissues for transmission electron microscopy. 


\section{LITERATURE CITED}

Azevedo C (1987) Fine structure of the microsporidian Abelspora portucalensis gen. n., sp. n. (Microsporida) parasite of the hepatopancreas of Carcinus maenas (Crustacea, Decapoda). J Invertebr Pathol 49:83-92

> Azevedo C, Corral L, Vivarès CP (2000) Ultrastructure of the microsporidian Inodosporus octospora (Thelohaniidae), a parasite of the shrimp Palaemon serratus (Crustacea, Decapoda). Dis Aquat Org 41:151-158

Bach SD, Beardsley GL (1976) A disease of the Florida spiny lobster. Sea Front 22:52-53

Behringer DC, Butler MJ IV, Shields JD (2006) Avoidance of disease in social lobsters. Nature 441:421

Behringer DC, Butler MJ IV, Shields JD (2008) Ecological and physiological effects of PaV1 infection on the Caribbean spiny lobster (Panulirus argus Latreille). J Exp Mar Biol Ecol 359:26-33

Butler MJ IV, Behringer DC, Shields JD (2008) Transmission of Panulirus argus virus 1 (PaV1) and its effect on the survival of juvenile Caribbean spiny lobster. Dis Aquat Org 79:173-182

Campillo A, Comps M (1977) Observation en Mediterranee de la microsporidie Ameson (Nosema) nelsoni (Sprague, 1950), un parasite de la crevette Parapenaeus longirostris Lucas. Rev Trav Inst Pech Marit 41:213-215

Couch JA, Fournie JW (eds) (1993) Pathobiology of marine and estuarine organisms. CRC Press, Boca Raton, FL

Dennis DM, Munday BL (1994) Microsporidiosis of palinurid lobsters from Australian waters. Bull Eur Assoc Fish Pathol $14: 16-18$

Evans LH, Jones JB, Brock JA (2000) Diseases of spiny lobster. In: Phillips BF, Kittaka J (eds) Spiny lobsters: fisheries and culture, 2nd edn. Fishing News Books, Blackwell Scientific Press, Oxford, p 461-471

FAO (Food and Agriculture Organization) (2001) Report of the workshop on management of the Caribbean spiny lobster (Panulirus argus) fisheries in the area of the Western Central Atlantic Fishery Commission. Merida, Mexico, 4-8 September 2000. FAO Fisheries Report No. 643, Rome

FAO (Food and Agriculture Organization) (2004) Fisheries global information system. Factsheet for Panulirus argus. Available at: www.fao.org/figis/servlet/species?fid=3445

Findley AM, Blakeney EW Jr, Weidner EH (1981) Ameson michaelis (microsporidia) in the blue crab, Callinectes sapidus: parasite-induced alterations in the biochemical composition of host tissues. Biol Bull (Woods Hole) 161:115-125

Hibbett DS, Binder M, Bischoff JF, Blackwell M and others (2007) A higher-level phylogenetic classification on the fungi. Mycol Res 111:509-547

Huchin-Mian JP, Rodríguez-Canul R, Arias-Bañuelos E, Simá-Álvarez R, Pérez-Vega JA, Briones-Fourzán P, Lozano-Álvarez E (2008) Presence of Panulirus argus Virus 1 (PaV1) in juvenile spiny lobsters Panulirus argus from the Caribbean coast of Mexico. Dis Aquat Org 79:153-156

Hunt JH (2000) Status of the fishery for Panulirus argus in Florida. In: Phillips BF, Kittaka J (eds) Spiny lobsters: fisheries and culture, 2nd edn. Fishing News Books, Blackwell Scientific Press, Oxford, p 189-199

Iversen ES, Manning RB (1959) A new microsporidian parasite from the pink shrimp (Penaeus duorarum). Trans Am Fish Soc 88:130-132
Jones TC, Hunt RD (1983) Veterinary pathology, 5th edn. Lea \& Febiger, Philadelphia, PA

Kruse DN (1959) Parasites of the commercial shrimps, Penaeus aztecus Ives, $P$. duorarum Burkenroad and $P$. setiferus (Linnaeus). Tulane Stud Zool 7:123-144

> Langdon JS (1991) Microsporidiosis due to a pleistophorid in marron, Cherax tenuimanus (Smith), (Decapoa: Parastacidae). J Fish Dis 14:33-44

Lightner DV (1996) A handbook of shrimp pathology and diagnostic procedures for diseases of cultured penaeid shrimp. The World Aquaculture Society, Baton Rouge, LA

Lightner DV, Pantoja CR, Poulos BT, Tang KFJ, Redman RM, Pasos-de-Andrade T, Bonami JR (2004) Infectious myonecrosis: new disease in Pacific white shrimp. Global Aquac Advocate 7:85

Olson R, Tiekotter E, Reno P (1994) Nadelspora canceri (n. g., n. sp.), an unusual microsporidian parasite of Dungeness crab (Cancer magister). J Eukaryot Microbiol 41:349-359

Poulos BT, Lightner DV (2006) Detection of infectious myonecrosis virus (IMNV) of penaeid shrimp by reversetranscriptase polymerase chain reaction (RT-PCR). Dis Aquat Org 73:69-72

Quintero-Hunter I, Grier H, Muscato M (1991) Enhancement of histological detail using metanil yellow as a counterstain in periodic acid/Schiff's hematoxylin staining of glycol methacrylate tissue sections. Biotech Histochem 66:169-172

Roberts RJ (ed) (1989) Fish pathology, 2nd edn. Baillière Tindall, London

Shields JD, Behringer DC Jr (2004) A new pathogenic virus in the Caribbean spiny lobster Panulirus argus from the Florida Keys. Dis Aquat Org 59:109-118

Shields JD, Wood FEI (1991) Pathology and fine structure of Ameson sp. a microsporidian from the blue sand crab Portunus pelagicus. Mem Queensl Mus 31:403

Shields JD, Stephens FJ, Jones B (2006) Pathogens, parasites and other symbionts. In: Phillips BF (ed) Lobsters: biology, management, aquaculture, and fisheries. Blackwell Publishing, Oxford, p 146-204

Sprague V, Couch J (1971) An annotated list of protozoan parasites, hyperparasites, and commensals of decapod crustacean. J Protozool 18:526-537

Stephens F, Evans LH, Jones B (2003) Diseases of mature spiny and clawed lobster. In: Evans LH (ed) A review of lobster diseases, their investigation and pre-disposing factors. Fisheries, Fisheries Research and Development Corporation Report FRDC Project No. 1999/202, Curtain University of Technology, Perth, p 42-62

Vivarès CP, Azevedo C (1988) Ultrastructural observations of the life cycle stages of Ameson atlanticum sp. nov., a microsporidan parasitizing Cancer pagurus L. J Fish Dis 11:379-387

Vivares CP, Sprague V (1979) The fine structure of Ameson pulvis (Microspora, Microsporida) and its implications regarding classification and chromosome cycle. J Invertebr Pathol 33:40-52

Vivarès CP, Bouix G, Manier JF (1977) Ormieresia carcini gen. n., sp. n., Microsporidie du crabe Meditérranéen, Carcinus mediterraneus Czerniavsky, 1884: Cycle évolutif et étude ultrastructurale. J Protozool 24:83-94

Wang W, Chen J (2007) Ultrastructural study on a novel microsporidian, Endorecticulatus eriocheir sp. nov. (Microsporidia, Encephalitozoonidae), parasite of Chinese mitten crab, Eriocheir sinensis (Crustacea, Decapoda). J Invert Pathol 94:77-83

Submitted: December 22, 2008; Accepted: February 12, 2009

Proofs received from author(s): April 10, 2009
Editorial responsibility: Ken Hasson, College Station, Texas, USA 